\title{
Situasi Politik Pemerintahan Dinasti Umayyah dan Abbasiyah
}

\author{
Munawir Haris \\ Sekolah Tinggi Agama Islam Negeri (STAIN) Sorong Papau Barat \\ irfani.fanani@gmail.com
}

Abstract: At the end of the Rasyidin Caliphate there was division within Muslims. Politically there are two dominant groups: Hasan bin Ali and Mu'awiyah bin Abi Sufyan. Politically there are two dominant groups, Hasan bin Ali and Mu'awiyah bin Abi Sufyan. After the negotiations, for the sake of unity of Muslims, it was agreed that Hasan acknowledged Mu'awiyah as the Caliph of the Muslim marked the emergence of the Umayyad Dynasty. The moment was called 'am jama'ah (unity year) in 661. The Abbasid Dynasty was the descendant of Prophet Muhammad's uncle, al-Abbas, who supported Ali bin Abi Talib and his descendants (including Hasan bin Ali). This paper aims to discuss some of the political situation that developed when the Umayyads (661-750) and the Abbasids (7501258). In Mu'awiyah bin Abi Sufyan's time there was a change of the political system from the khulafaur Rashidin into a system of al-Mulk (heredity monarchy) characterized by the appointment of his son, Yazin bin Mu'awiyah. This system adopted from the Persian and Byzantine kingdoms. However, maintaining the term caliph of Islam. Mu'awiyah also used Diwan and Sheikh to run the government, with the mechanism of Shura for consultative functions. After 150 years the Umayyads, the power was changed over by Abu al-Abbas Abdullah and marked the rising of the Abbasid in 750. In the Abbasid period the political and religious issues can't 
be separated, which earlier in the Umayyad period were separated. The propaganda that the caliph is the representative of the people in carrying out God's command is valid until the Judgment Day. More explicitly, the term al-Imam (which also means the leader of prayer) is the leader in political affairs. In addition, the implementation of Islamic Shari'a is also more highlighted in governing the government and legitimating the power of the caliph. In general, the political style of the Abbasids is more Persian than the more Arab Umayyads.

Keywords: Caliph of the Muslim, Political Situation, Umayyad Dynasty, Abbasid Dynasty, Mu'awiyah bin Abi Sufyan, Hasan bin Ali and Abu al-Abbas Abdullah.

\section{Pendahuluan}

Asas dari pembentukan khilafah atau Dinasti Umayyah muncul sesaat setelah bersatunya umat Islam kembali yang pada waktu itu lebih populer dikatakan dengan sebutan "tahun persatuan". Hasan ibn Ali ibn Abi Thalib turun dari jabatannya sebagai khalifah dan diserahkan kepada Mu’awiyah. Mu’awiyah ibn Abi Sufyan (selanjutnya baca: Mu'awiyah) disebut-sebut sebagai khalifah pertama Dinasti Umayyah dan sekaligus sebagai pendirinya. Mu'awiyah telah masuk Islam sebelum ayahnya, Abi Sufyan, yakni pada umrah qadha' dan menyatakan keislamannya pada hari penaklukan kota Mekkah. Mu'awiyah adalah orang yang berperawakan tinggi, berkulit putih, gagah, dan berwibawa. ${ }^{1}$ Dalam membangun Dinasti Umayyah, Mu'awiyah menjalankan sistem pemerintahan yang sangat jauh berbeda dengan pemerintahan masa Khulafa' al-Rasyidin. Sistem pemerintahan masa Dinasti Bani Umayyah tidak lagi didasari atas asas musyawarah dan baiat, tetapi telah beralih ke pemerintahan monarki. Periode Khilafah Rasyidah dimulai sejak Abu Bakar

1 Syamsuddin Muhammad bin Ahmad bin Usman al-Zahabiy, Tarikh al-Islam wa Wafayat al-Masyahir wa al-A'lam ahdu Mu'awiyah ibn Abi Sufyan, Cet. II (Beirut: Dar al-Kitab al-Arabi, 1992M/1413 H), 308. 
hingga Ali bin Abi Thalib dan para khalifahnya disebut sebagai Khulafa' al-Rayidin (khalifah yang mendapat petunjuk). Dan ciri yang paling menonjol dari masa ini adalah khalifah benar-benar meneladani sikap dan perilaku Nabi Muhammad Saw. Sedangkan, setelah masa ini pemerintahan Islam justru berbentuk kerajaan. Kekuasaan diwariskan secara turun-temurun. Para penguasa Dinasti Umayyah dalam memerintah seringkali bertindak otoriter. ${ }^{2}$ Meski demikian, pemerintahan Dinasti Bani Umayyah telah memberikan sumbangan yang besar untuk kemajuan peradaban Islam dan perluasan wilayah Islam dengan berbagai ekspansi Dinasti Bani Umayyah.

Setelah runtuh, Dinasti Bani Umayyah diganti dengan pemerintahan Dinasti Bani Abbasiyah yang memegang peranan penting dalam perkembangan sejarah peradaban umat Islam. Dinasti Bani Abbasiyah menjadi kekhalifahan yang terlama di dunia, yaitu berlangsung selama 524 tahun sejak tahun 12-656 H (750-1258 M) yang dapat dibagi atas tiga periode. Periode pertama, pemerintahan dikuasai oleh khalifah dan menguasai semua kerajaan Islam yang berkembang ke beberapa penjuru dunia mulai Utara dan Barat India Afghanistan, Armenia, Palestina, Mesir, sampai Afrika timur. ${ }^{3}$ Pada masa ini (132-232 H) Dinasti Bani Abbasiyah mencapai puncak kejayaannya (masa keemasan), di antaranya dengan berkembangnya filsafat dan ilmu pengetahuan. Periode kedua (232-656 $\mathrm{H})$, pemerintahan tidak lagi dikuasai oleh para khalifah. Periode ketiga (590-656 H), pemerintahan terpecah-pecah menjadi negara kecil.

Pada masa kejayaan Bani Abbas, khalifah Abdul Abbas al-Safah dan khalifah Abu Ja'far berhasil mempertahankan serta menumpas musuhmusuhnya. Setelah tercapai kemenangan, maka terbukalah peluang besar dalam menciptakan kestabilan pemerintahan dengan menata kembali dan mengembangkan berbagai bidang yang belum dimaksimalkan. Keuangan diberdayakan, perundang-undangan dibuat, dan ilmu pengetahuan dikembangkan.

2 Badri Yatim, Sejarah Peradaban Islam: Dirasah Islamiyah II, Cet. xiv (Jakarta: PT. Raja Grafindo Persada, 2003), 42.

3 Ibid., 92. 


\section{Awal Pembentukan Dinasti Umayyah}

Setelah terbunuhnya khalifah Ali bin Abi Thalib, maka kedudukannya digantikan dan dijabat oleh anaknya Hasan. Ia memegang kekhalifahan setelah kematian ayahnya, Ali bin Abi Thalib dengan pembaiatan yang dilakukan oleh orang-arang yang ada di Kufah (suatu kota yang ada di Irak, bagian Barat dari sungai Eufrat) dan tinggal di sana selama kurang lebih enam bulan. Pada suatu hari datanglah Mu’awiyah bin Abi Sufyan kepada Hasan dengan melakukan perundingan. Dia berupaya agar Hasan menyerahkan kekuasaan khalifah kepadanya dengan syarat tidak seorang pun menuntut kepadanya dari kalangan orang-orang Madinah, Hijaz, dan Irak.

Permasalahan yang terjadi pada masa ayahnya, Ali bin Abi Thalib dengan menunaikan ataupun melepaskan segala hutang-hutangnya dan itu disanggupi oleh Mu'awiyah seperti yang diinginkan oleh Hasan dan karenanya ia pun membuat perjanjian damai. Maka tercapailah perdamaian di antara kedua belah pihak. Perjanjian inilah yang kemudian akhirnya dapat mempersatukan Islam kembali dalam satu kepemimpinan politik, kepemimpinan Mu’awiyah bin Abi Sufyan. Di sisi lain, perjanjian itu juga menyebabkan Mu'awiyah menjadi penguasa yang absolut dalam sejarah pemerintahan Islam. Di mana tahun $41 \mathrm{H} / 661 \mathrm{M}$ atau tahun persatuan dikenal dalam sejarah sebagai tahun bersatunya umat Islam ('am jama'ah). ${ }^{4}$ Selain itu, 'am jama'ah juga menandai akhir dari era Khulafa' al-Rasyidin dan awal era pemerintahan kerajaan; dimulainya kekuasaan Dinasti Bani Umayyah dalam belantika sejarah politik Islam. Seorang pemikir Islam, as-Suyuthi mengemukakan bahwa peristiwa itu merupakan wujud dari mu'jizat nabawiyyah dalam sebuah Hadis, "Allah Swt. akan mendamaikan dua kelompok yang bertikai dari kalangan muslim." Hasan Ali bin Abi Thalib R.a. turun sebagai khalifah pada $41 \mathrm{H}$ pada bulan Rabi'ul Awal-sebagian pendapat menyebut Jumadil Awal—untuk menghindari pertikaian yang terjadi dalam pemerintahan Islam. Hasan kemudian meninggalkan kota Kufah menuju Madinah dan tinggal di

\footnotetext{
4 Hasan Ibrahim Hasan, Sejarah dan Kebudayaan Islam (Yogyakarta: Penerbit Kota Kembang, 1989), 64.
} 
kota tersebut sampai ia meninggal karena diracuni oleh istrinya sendiri Ja'dah binti Asy'ast bin Qaish yang belakangan kemudian diperistri oleh Yazid bin Mu'awiyah bin Abi Sufyan dan wafat pada tahun $49 \mathrm{H}$ atau 5 Rabi'ul Awal 50 H. ${ }^{5}$

Sebagai khalifah atau raja pertama Dinasti Bani Umayyah, Mu’awiyah bin Abi Sufyan (661-680 M) membentuk pemerintahannya sebagaimana sistem kerajaan; kekuasaan diwariskan secara turun-temurun, dan khalifah-khalifah setelahnya kerap kali bertindak otoriter. Meski anak dari pasangan Sufyan bin Harb dan Hindun binti Utbah bin Rabi'ah, Mu'awiyah bin Abi Sufyan adalah salah seorang sahabat Rasulullah Saw. Ayahnya adalah salah seorang dari pembesar atau tokoh Quraisy di zaman jahiliyah, pemimpin yang dihormati dan disegani, serta memiliki harta yang banyak. Mu’awiyah adalah satu di antara beberapa orang sahabat yang menjadi penulis wahyu. Bahkan, ia pernah meminta kepada Rasulullah Saw. supaya memperisteri anak perempuannya, yaitu Azzah binti Abi Sufyan, akan tetapi tidak terjadi. Ketika daerah Syam bisa ditaklukkan, khalifah Umar menjadikan Mu'awiyah sebagai walinya (gubernur) untuk kota Damaskus setelah saudaranya Yazid bin Abi Sufyan, dan tetap diteruskan pada masa Khalifah Usman bin Affan, bahkan daerah kekuasaannya ditambah. Akhirnya, Mu'awiyah berhasil membangun pusat pemerintahan di kota Damaskus dan berkuasa selama 40 tahun.

Namun, ketika Khalifah Usman dibunuh, penggantinya Khalifah Ali bin Abi Thalib memberikan isyarat kepada Mu'awiyah dan pembesarpembesar lainnya yang terlibat dalam pembunuhan Khalifah Usman agar turun dari jabatannya. Meski Mu'awiyah telah dipecat sebagai gubernur Syam, tetapi penduduk Syam tetap berpihak kepadanya dan bahkan menentang Ali. Mu'awiyah mengatakan bahwa dia tidak akan membaiat Ali bin Abi Thalib sebagai khalifah sampai diserahkannya orang-orang yang membunuh Usman. Mu'awiyah beranggapan bahwa Usman dibunuh dengan cara yang zalim, maka kemudian terjadi peris-

\footnotetext{
5 Jalal al-Din al-Suyuthi, Tarikh al-Khulafa wa al-Umara, Cet. I (t.tp.: t.p, 1408H/1988M), 152-154.
} 
tiwa Perang Shiffin yang keputusannya beralih secara tahkim melalui perwakilan Ali yaitu Abu Musa al-Asy'ari dan perawakilan Mu'awiyah yakni Amr bin Ash untuk melakukan perundingan; sebuah perundingan yang merugikan pihak Ali bin Abi Thalib, karena pihak Mu'awiyah ingkar terhadap perjanjian. Akibatnya perselisihan semakin memanas yang membuat sebagian kalangan membentuk kelompok ketiga, pihak yang kecewa dengan Ali dan Mu'awiyah, ialah golongan Khawarij. Umat Islam terpecah menjadi tiga golongan. Belakangan salah seorang khawarij dari kota Kufah yang bernama Abd al-Rahman bin Muljam diketahui membunuh khalifah terakhir, Ali bin Abi Thalib. Para sahabat dan pengikut Ali yang kebanyakan penduduk Irak kemudian membaiat Hasan bin Ali bin Abi Thalib R.a. ${ }^{6}$ Tetapi hampir di saat yang bersamaan penduduk Syam juga membaiat Mu'awiyah sebagai khalifah. Hasan memegang dan memimpin pasukan Irak, sedangkan pasukan dari Syam dimotori oleh Mu'awiyah. Ketika dua pasukan itu berjumpa, maka diupayakan agar diadakan perjanjian damai. Hasan akhirnya melepaskan jabatan khalifah dan menyerahkan kekuasaan kepada Mu'awiyah, dan sejak detik itu pula tongkat kekhalifahan berada di tangan Mu'awiyah yang kemudian dikenal sebagai tahun persatuan ('am jamaah) sebagaimana disebutkan.

Sebetulnya, jauh sebelumnya masyarakat Syam telah membaiat Mu'awiyah sebagai khalifah yakni setelah tragedi arbitrase (tahkim) tahun $37 \mathrm{H}$, sementara pembaiatan secara umum dilakukan setelah perjanjian damai tahun $41 \mathrm{H}$. Mu'awiyah menyerahkan perwalian Syam kepada Fadhalah bin Ubaid, kemudian setelahnya kepada Abi Idris Khaulani. Pengawalan dipimpin Qais bin Hamzah, sementara Sarjun bin Manshur al-Rumi ditunjuk sebagai sekretaris sekaligus asistennya. Mu'awiyah adalah khalifah yang pertama kali mengangkat pengawal atau penjaga dan menerapkan sistem pemerintahan monarchi heridetis (kerajaan turun-temurun). Yang mesti digarisbawahi adalah bahwa pada hakikatnya pembaiatan secara umum ('am al-jama'ah) tidak lebih dari pengakuan secara terpaksa dalam upaya menjaga kesatuan umat. Atau

6 'Imad al-Din Abi al-Fida Ismail bin Umar Katsir al-Qursy Dimasyq, Bidayah wa al-Nihaya, Juz II, Cet. I (Beirut: Dar al-Hijr, 1418/1998), 146-147. 
dengan kata lain masuknya unsur kekuasaan dan keterpaksaan menggantikan kesukarelaan total atau permusyawaratan. Asas yang mendasari sistem kekhalifahan telah menyimpang ke arah sistem monarki. ${ }^{7}$ Berbagai opini pun kemudian muncul dari sejumlah kelompok Islam mengenai kekhalifahan Mu'awiyah. Kelompok Ahl al-Sunnah wa al-Jamaah, misalnya, mengakui kekhalifahannya beberapa saat setelah tahun persatuan, meskipun memang lebih terkesan dan banyak didorong oleh tendensi akan realitas, sebab menurut mereka kekhalifahan Mu'awiyah belum berdiri atas dasar pembaiatan yang bebas dan umum. Pandangan yang berseberangan dengan kelompok ini datang dari kaum Syiah, bahwa mereka hanya mengakui kekhalifahan Ali dan anak keturunannya, serta berpandangan bahwa kelompok selain Syi'ah adalah perampas hak-hak mereka. Dan karena itu pula mareka tidak mengakui sama sekali kekhalifahan Mu'awiyah dan khalifah berikutnya. ${ }^{8}$

\section{Situasi Politik pada Masa Mu'awiyah bin Abi Sufyan}

Sebagaimana dikemukakan bahwa Mu'awiyah adalah awal kekuasaan Bani Umayyah, yang menerapkan monarchi heridetis (kerajaan turun-temurun) sebagai ganti dari pemerintahan kekhalifahan yang demokratis. Berdasarkan data sejarah yang ada di atas dapat disimpulkan bahwa kekhalifahan Mu'awiyah diperoleh dengan dan melalui diplomasi, kekerasan, tipu daya, dan tidak melalui pemilihan dengan suara terbanyak. Pada mulanya Mu'awiyah secara khusus tidak menginginkan adanya perubahan sama sekali. Dia menghormati kekuatan-kekuatan yang ada, dengan tetap membatasi dirinya pada penyeimbangan secara bijaksana antara satu kesatuan denga kekuatan lainnya. Dia juga sangat berhati-hati untuk memperlakukan kekuatan berbagai kelompok suku yang ada. Sebagai contoh, mereka yang mendukung 'Ali diperlakukannya dengan "penghormatan" dan kebesaran yang tak terduga dan tanpa

7 Muh. Dhiau al-Din Rais, Al-Nazhariyah al-Siyasiyyah al-Islamiyah (Teori Politik Islam) terj. Abdul Hayyie el-Kattani, dkk., Cet. VI (Jakarta: Gema Insani Press, 2001), 140.

8 Ibid., 141. 
rasa malu, dan sebaliknya justru dia menerima dukungan mereka yang diperlukannya. ${ }^{9}$ Kesuksesan kepemimpinan secara turun-temurun sesungguhnya dimulai ketika Mu'awiyah mewajibkan seluruh rakyatnya untuk menyatakan setia kepada anaknya, Yazid. Dilihat dari bentuk pemerintahannya, sebenarnya Mu'awiyah bermaksud mencontoh monarki di Persia dan Byzantium. ${ }^{10}$ Dalam buku-buku sejarah menyebutkan bahwa ide awal pewarisan kekhalifahan berasal dari al-Mughirah ibn Syu'bah, ${ }^{11}$ yang kala itu menjabat sebagai gubernur Kufah di masa Mu’awiyah. Justru dialah yang memberi saran kepada Mu'awiyah untuk mengangkat anaknya Yazid untuk menjadi khalifah penggantinya. Ketika itu, Mu'awiyah juga sudah meminta pandangan Ziyad, Gubernur Basrah pada waktu itu berkenan dengan hal tersebut. Dengan pertimbangan Ziyad, Mu'awiyah tidak tergesa-gesa dan bertindak gegabah dalam mengambil keputusan. Tetapi setelah kematian Ziyad, keinginan untuk menjadikan anaknya sebagai putra mahkota kembali menguat dan semakin bulat. ${ }^{12}$

9 M.A. Shaban, Sejarah Islam (600-750): Penafsiran Baru, terj. Machnun Husein, Cet. I (Jakarta: PT. Raja Grafindo, 1993), 115.

${ }^{10}$ Suatu perubahan besar dari segi sistem pemerintahan terjadi pada masa Mu'awiyah berkuasa. Sejak masa pemerintahan Rasul Saw sehingga Ali bin Abi Thalib, sistem pemerintahan yang digunakan adalah sistem Khilafah an-Nubuwah (pemerintahan profetik), dimana setiap khalifah berperan ganda dalam menggantikan posisi kenabian dalam hal kepala negara dan pemimpin umat Islam. Pada masa Dinasti Umayyah, Mu'awiyah dengan pengalaman hubungan luar negeri selama berpuluh-puluh tahun mencoba untuk mengeksiskan sistem pemerintahan baru, yaitu sistem al-Mulk (kerajaan/imperium). Perubahan sistem tersebut dilakukan dengan cara meniru sistem yang berkembang pada pemerintahan Persia, Byzantium, dan Ethiopia pada masa itu. Lihat misalnya dalam Philip K. Hitti, History of The Arabs: From Earliest Times to the Present (New York: Palgrave Macmillan, 2002), 240.

${ }^{11}$ Abi Ja'far Muhammad ibn Jarir al-Thabari, Tarikh al-Umaml wa al-Muluk, Juz V (Kairo: Rawa'i Turats Arabi, 1387/1967), 301.

${ }^{12}$ Mu'awiyah mempunyai beberapa alasan mengenai pengangkatan Yazid, yaitu: Pertama, Yazid adalah satu-satunya orang yang bisa diterima orang-orang Siria, karena apabila dari keluarga lain akan membawa ke dalam keluarga dan marganya sesuatu yang mengganggu keseimbangan kekuatan-kekuatan rawan yang telah dikembangkan oleh mu'awiyah. Kedua, faktor usia mu'awiyah yang sudah tua mendesaknya untuk cepat memilih siapa penggantinya, Ketiga, Mu'awiyah khawatir akan terjadi fitnah seba- 
Tak dapat disangkal bahwa Mu’awiyah dalam memimpin masih tetap menggunakan istilah khalifah, namun dia memberikan interpretasi baru dari kata-kata itu untuk mengagungkan jabatan tersebut. Dia menyebutnya "khalifah Allah", dalam pengertian penguasa yang diangkat oleh Allah. ${ }^{13}$ Kekuasaan Bani Umayyah berumur kurang lebih 90 tahun. Oleh Mu'awiyah bin Abi Sofyan ibu kota negara yang sebelumnya di Madinah dipindahkan ke Damaskus. Pemindahan ibu kota dari Madinah ke Damaskus melambangkan zaman imperium baru dengan menggesernya untuk selama-lamanya dari pusat Arabia, yakni Madinah yang merupakan pusat agama dan politik kepada sebuah kota yang kosmopolitan. Dari kota inilah Daulah Umayyah melanjutkan ekspansi kekuasaan Islam dan mengembangkan pemerintahan sentral yang kuat, yaitu sebuah imperium Arab. ${ }^{14}$ Ekspansi yang berhasil dilakukan pada masa Mu'awiyah antara lain ke wilayah-wilayah: Tunisia, Khurasan sampai ke Sungai Oxus, Afganistan sampai ke Kabul, kemudian dilanjutkan ke Byzantium, bahkan sampai ke India dan dapat menguasai daerah Balukistan, Sind, dan daerah Punjab sampai ke Maltan. ${ }^{15}$ Konsolidasi internal dilakukan sejak masa pemerintahan Mu'awiyah dengan tujuan untuk memperkokoh barisan dalam rangka pertahanan dan keamanan dalam negeri, antisipasi atas setiap gerakan pemberontakan, dan untuk memperlancar program pemerintah. Idealnya konsolidasi tersebut dijadikan sebagai prasarana menuju keberhasilan programprogram dinasti. Ada lima Diwan al-Jund (Dinas Urusan Kemiliteran), Diwan ar-Rasail (Dinas Urusan Administrasi dan Surat atau The Board of Correspondence), Diwan al-Barid (Dinas Urusan Pos atau The Board

gaimana fitnah pertumpahan darah sejak kematian Khalifah Utsman. Lihat John L. Esposito, Ensiklopedi Oxford: Dunia Islam Modern, Jilid VI, 97-99.

${ }^{13}$ Mengenai term sistem pemerintahan masa khilafah Rasyidah dan masa dinasti Umayyah berikut perbedaan keduanya. Lihat Abul A'la al-Maududi, Al-khilafah wa al- Mulk (Khilafah dan Kerajaan: Evaluasi Kritis atas Sejarah Pemerintahan Islam), terj. Muhammad al-Baqir, Cet. VII ( Bandung: Mizan, 1998), 63-67.

${ }^{14}$ Hitti, History of the Arabs, 242.

${ }^{15}$ Harun Nasution, Islam Ditinjau dari Berbagai Aspeknya, Jilid I, Cet. V (Jakarta: UI Press 1990), 58-61. 
of Posts), Diwan al-Kharaj (Dinas Urusan Keuangan atau the Board of Finance), dan Diwan al-Khatam (Dinas Urusan Dokumentasi atau the Board of Signet). ${ }^{16}$ Instrumen tertinggi dalam pemerintahan yang bercorak Arab adalah Syura, sebuah diwan (kansil), syaikh yang ditunjuk oleh khalifah atau oleh gubernur provinsi, dengan fungsi konsultatif dan eksekutif. Mu'awiyah sendiri jarang memberi perintah, tetapi dalam melaksanakan pemerintahannya cukup melalui proses yang dapat diandalkan berdasarkan kepercayaan dan melalui proses yang dapat diandalkan berdasarkan kepercayaan dan melalui kemampuan, serta pengaruh pribadinya. Jasa-jasa dalam pembangunan di berbagai bidang banyak dilakukan pada masa pemerintahannya. Mu'awiyah mendirikan dinas pos, menertibkan angkatan bersenjata, mencetak mata uang, dan jabatan qadhi (hakim), mulai berkembang menjadi profesi sendiri. Selain itu, jenis atau pola pemerintahan terdahulu mulai berubah sejak zaman Mu'awiyah. Walaupun berbentuk kerajaan, Mu'awiyah tetap membuktikan eksistensinya dengan terus membuat kemajuan-kemajuan. ${ }^{17}$

\section{Dinasti Abbasiyah}

Bani Abbas adalah keturunan dari al-Abbas paman Rasulullah Saw. Pada dasarnya selama abad pertama hijriyah, keturunan al-Abbas sama sekali tidak pernah berniat untuk memegang kekhalifahan, mereka hanya memusatkan dukungan kepada keturunan Ali ibn Abi Thalib serta memperjuangkan hak mereka atas khilafah. ${ }^{18} \mathrm{Al}$-Abbas sangat meyakini hak Ali atas khilafah yang kemudian diikuti oleh anaknya Abdullah. Ketika ia dikaruniai anak laki-laki ia memberinya nama Ali sebagai bukti penghargaannya kepada Ali. Ali ini kemudian memperjuangkan keyakinan

\footnotetext{
${ }^{16}$ Ahmad Amin, Yaum al-Islam (Islam dari Masa ke Masa) terj. Abu Laila \& M. Tohir, Cet. III (Bandung: PT. Remaja Rosdakarya Bandung, 1993), 99-100.

${ }^{17}$ Bernard Lewis, The Arabs in History (Bangsa Arab Dalam Lintasan Sejarah: Dari Segi Geografi, Sosial, Budayam dan Peranan Islam), terj. Said Jamhuri, Cet. II (Jakarta: Pedoman Ilmu Jaya, 1994), 58.

${ }^{18}$ Ibrahim Ahmad al-Adawiy, Tarikh al-A'lam al-Islamiy, Juz I (Kairo: Ma'had al-Dirasat al-Islamiyyah, 1982), 195.
} 
keluarganya mengenai hak Ali dan keturunannya atas khilafah. Untuk mengantisipasi kemungkinan tuntutan keturunan Ali dan keturunan alAbbas, Khalifah Umayyah' Abd al-Malik ibn Marwan memanggil Ali ibn Abdullah beserta keluarga dan beberapa keturunan Ali ibn Abi Thalib dengan menyediakan sebuah kawasan bermukim di Hamimah (sebelah Timur Yordania). Hal ini dalam rangka kepentingan kontrol dan pengawasan terhadap mereka. ${ }^{19}$

Kegiatan propaganda secara terang-terangan pada masa khalifah terakhir Umayyah, Marwan Ibn Muhammad, dipusatkan di Khurasan dan dengan cepat dapat menguasai ibu kota Maruw. Hal tersebut membuat wali Umawiy di sana meminta bantuan ke pusat. Pusat tidak tahu sama sekali kepada siapa tuntutan khilafah tersebut ditujukan hingga tibanya kitab rencana dan kegiatan propaganda Ibrahim al-Abbasiy kepada Marwan ibn Muhammad. Segera khalifah memerintahkan penangkapan atas Ibrahim, namun sebelumnya Ibrahim mewasiatkan saudaranya Abu al-Abbas untuk menjadi al-Imam dan menginstruksikannya ke Kufah. Sebelum didahului oleh Abu Salamah al-Khilal yang berniat untuk mengambil alih posisi al-imam, Abu al-Abbas dengan dibantu Abu Muslim menghambat usaha Abu Salamah tersebut, Abu Muslim yang telah resmi sebagai panglima pemberontak mengirim orangnya ke Kufah untuk segera membaiat Abu al-Abbas. Dengan terpaksa Abu Salamah turut membaiat. Setelah dibaiat Abu al-Abbas segera memusatkan usahanya untuk menghancurkan Marwan Ibn Muhammad Khalifah Umayyah terakhir, terjadilah Perang al-Zab, ${ }^{20}$ yang dalam sejarah disebut sebagai salah satu perang yang sangat hebat. Tentara Bani Abbas dipimpin oleh paman Abu al-Abbas, Abdullah ibn Ali, sedangkan tentara Umayyah dipimpin langsung oleh Khalifah Marwan ibn Muhammad. Tentara Umayyah mengalami kekalahan dan mundur ke

\footnotetext{
${ }^{19}$ Ahmad Mukhtar al-'Abbadiy, Fi al-Tarikh al-Abbasiy wa al-Fatimiy (Beirut: Dar al-Nahdah al-Arabiyyah, t.t), 19.

${ }^{20}$ Perang ini berlangsung di sekitar sungai al-Zab salah satu cabang Sungai Dajlah di dekat al-Musul utara Irak. Perang ini berlangsung pada akhir bulan Jumadil Akhir 132 $\mathrm{H}$ (Januari $750 \mathrm{M}$ ). Kronologis perang ini dapat ditemui di dalam kitab-kitab sejarah Islam.
} 
Damaskus. Tentara Abbasiyah terus mengejar dan memasuki Damaskus, satu per satu daerah Syiria dapat ditaklukkan. Marwan ibn Muhammad akhirnya tertangkap di Mesir dan terbunuh pada bulan Zulhijjah $132 \mathrm{H} /$ 750 M. Secara resmi kekhalifahan Umayyah runtuh dan digantikan oleh Abbasiyah, kekhalifahan baru dengan khalifah pertama Abu al-Abbas, 'Abdullah Ibn Muhammad ibn Ali ibn Abdullah ibn al-Abbas yang terkenal dengan gelar al-Shaffah (Sang Pembantai). ${ }^{21}$ Damaskus tetap menjadi ibu kota kekhalifahan, dan baru pada masa Abu Ja'far al-Mansur khalifah kedua, ibu kota dipindahkan ke Baghdad.

\section{Ciri-Giri Khusus Daulah Abbasiyah}

Daulah Abbasiyah sebagai sebuah kekhalifahan baru mempunyai perbedaan yang sangat signifikan dengan Daulah Umayyah sebelumnya. Selain domisili Arab pada pemerintahan yang digantikan oleh Persia, Turki dan Mawaliy ada beberapa perbedaan dari berbagai dimensi sebagai berikut:

Para khalifah Abbasiyah berusaha memberi Daulah mereka sifat kesucian (qadasah), dengan menjadikan pemerintahan mereka bersumber dari syariat Allah, berbeda dengan Daulah Umayyah yang Arab sentris membuat para khalifah seperti seorang kabilah. Hal ini berpengaruh terhadap sistem pemerintahan yang bersumberkan kepada hal-hal yang bersifat materil. ${ }^{22}$ Dalam artian bahwa kedudukan khalifah Abbasiyah adalah pemberian dari Allah bukan dari rakyat. Hal ini berpengaruh kepada kehidupan pemerintahan. Para khalifah menamakan

${ }^{21}$ Terjadinya kontroversi atas gelar al-Shaffah ini, sebagian sejarawan menisbahkan gelar ini kepada paman Abu al-Abbas, yaitu Abdullah Ibn Ali yang sangat keji dan tidak segan-segan membantai semua keturunan Umayyah. Bahkan dalam riwayat ia memerintahkan untuk menggali semua kuburan khalifah Umayyah untuk kemudian dibakar, kecuali Umar ibn Abd al-Aziz. Selain itu, mereka juga melihat bahwa sosok Abu al-Abbas yang sangat agamis dan bertentangan dengan predikat al-Shiffin tersebut. Lengkapnya lihat al-Abbadiy, Fi al-Tarikh al-Abbasiy, 41-43; lihat juga Mustafa Zakiy Mustafa Muhammad, Tarikh al-Daulah al-Abbasiyah (Kairo: Buku Teks Fak. Studi Islam, Universitas al-Azhar, 1994-1995), 47.

${ }^{22}$ al-Abbadiy, Fi al-Tarikh al-Abbasiy, 30. 
diri mereka al-Imam yang pada masa sebelumnya dipakai pada pemimpin shalat Sistem kerajaan pun diwarnai dengan berbagai macam upacara dan etiket, khalifah tidak dapat ditemui langsung sebelum melalui beberapa al-hajib (semacam protokoler).

Dimensi keagamaan dan keyakinan bahwa khalifah menjalankan perintah Tuhan dipercayai oleh masyarakat. Ini tadak terlepas dari usaha para propagandis yang dalam usahanya tersebut sering memakai HadisHadis Nabi yang tidak akurat atau shahih, yang menegaskan bahwa hak tersebut berlanjut hingga hari kiamat. ${ }^{23}$ Mungkin inilah sebab keberhasilan mereka dalam menggalang massa untuk melawan pemerintahan Bani Umayyah. Dan hal ini juga yang membuat pemerintahan mereka dapat bertahan lama.

Pada pemerintahan Abbasiyah masalah politik dan agama menyatu, berbeda pada masa sebelumnya yang memusatkan pemerintahan pada masalah keduniawian. Tampak pada berbagai macam pemberontakan yang terjadi, selalu berangkat dari masalah keagamaan. Para khalifah Abbasiyah mengatakan bahwa mereka berusaha menegakkan keadilan dan menghidupkan sunnah. ${ }^{24}$ Karena adanya pembauran masalah politik dan agama, hal ini membuat rakyat harus taat kepada khalifah sebagai sebuah bagian dari ritual keagamaan. Pada masalah politik ini juga jabatan-jabatan yang ada dalam pemerintahan banyak mengadopsi dari Persia seperti adanya wazir, al-hajib, dan beberapa birokrasi istana. Berbeda dari Dinasti Umayyah, Abbasiyah tidak lagi melakukan perluasan wilayah, akan tetapi hanya mempertahankan batas wilayah, memberi pelajaran kepada kerajaan yang menyalahi perjanjian dan menyerang kelompok pemberontak. Tidak adanya perluasan wilayah tidaklah menandakan Daulah Abbasiyah lemah, tapi sebaliknya Daulah Abbasiyah sangat kuat dari segala segi. ${ }^{25}$ Daulah Abbasiyah adalah daulah Islam yang berumur paling lama dengan umur sekitar 524 Tahun. Sebanyak 37

\footnotetext{
${ }^{23} \mathrm{Ibid}, 31$.

${ }^{24} \mathrm{Ibid}, 32$.

${ }^{25}$ Nadiah Mahmud Mustafa, al-Daulah al-Abbasiyah; min al-Takhalliy'an Siyasat al-Fath ila al-Suqut, Cet. I (Kairo: al-Ma'had al-'Alamiy li al-Fikr al-Islamiy, 1996), 17.
} 
khalifah secara bergantian memegang pemerintahan, namun hanya pada masa sembilan khalifah pertama Daulah Abbasiyah mengalami masa keemasan.

\section{Penutup}

Berdasarkan uraian tersebut di atas dapat dikemukakan beberapa kesimpulan: Mu'awiyah bin Abi Sufyan adalah khalifah yang pertama kali meletakkan prinsip pewarisan atau imperium (al-mulk) dalam kekuasaan pemerintahan Islam yang berbeda dengan pemerintahan Khulafa al-Rasyidin. Dapat dikatakan bahwa kondisi pemerintahan pada masa Mu'awiyah cukup stabil. Pemerintahan Islam meskipun telah bercampurbaur unsur kerajaan dengan sistem pewarisan, makna-makna substansi dan tujuan-tujuan serta hakikat kekhalifahan masih utuh. Walaupun terjadi perselisihan atau perpecahan dari masa ke masa, negara Islam dengan bentuk apapun masih terus berjalan. Adapun Bani Abbasiyah mulanya hanya mendukung Bani Ali untuk merebut kursi khilafah, namun karena wasiat Abu Hasyim, mereka akhirnya berjuang dengan propaganda untuk merebut khilafah untuk kaumnya. Sedangkan ciri yang cukup menonjol pada Daulah Abbasiyah adalah tersingkirnya dominasi Arab seperti pada masa Umayyah dan digantikan oleh ras Persia dan Turki. Selain itu, terdapat perbedaan menyolok dengan Daulah Umayyah dalam hal masalah urusan keagamaan dan politik pemerintahan. 


\section{Daitar Pustaka}

Amin, Ahmad. Yaum al-Islam (Islam dari Masa ke Masa), terj. Abu Laila \& M. Tohir. Cet. III. Bandung: PT. Remaja Rosdakarya, 1993.

al-Abbadiy, Ahmad Mukhtar. Fi al-Tarikh al-Abbasiy wa al-Fatimiy. Beirut: Dar al-Nahdah al-Arabiyyah, t.t.

al-Adawiy, Ibrahim Ahmad. Tarikh al-A'lam al-Islamiy. Juz I. Kairo: Ma'had al-Dirasat al-Islamiyyah, 1982.

al-Baqir, Muhammad. Khilafah dan Kerajaan: Evaluasi Kritis atas Sejarah Pemerintahan Islam. Cet. VII. Bandung: Mizan, 1998.

al-Din, Rais Muh. Dhiau. Al-Nazhariyah al-Siyasiyyah al-Islamiyah (Teori Politik Islam), terj. Abdul Hayyie el-Kattani, dkk. Cet. VI. Jakarta: Gema Insani Press, 2001.

al-Qursy, 'Imad al-Din Abi al-Fida Ismail bin Umar Katsir. Bidayah wa al-Nihaya, Juz II. Beirut: Dar al-Hijr, 1418 H/1998 M.

al-Thabari, Abi Ja'far Muhammad ibn Jarir. Tarikh al-Umaml wa alMuluk, Juz V. Kairo: Rawa'i Turats Arabi, 1387 H/1967 M.

Esposito, John L. The Oxford Encyclopedia of the Modern Islamic World (Ensiklopedi Oxford: Dunia Islam Modern), Jilid VI. New York: Oxford University, 1998.

Hasan, Ibrahim. Sejarah dan Kebudayaan Islam. Yogyakarta: Penerbit Kota Kembang, 1989.

K. Hitti, Philip. History of the Arabs: From Earliest Times to the Present. New York: Palgrave Macmillan, 2002.

Lewis, Bernard, The Arabs in History (Bangsa Arab dalam Lintasan Sejarah: Dari Segi Geografi, Sosial, Budaya, dan Peranan Islam), terj. Said Jamhuri. Cet. II. Jakarta: Pedoman Ilmu Jaya, 1994.

Muhammad, Mustafa. Tarikh al-Daulah al-Abbasiyah. Kairo: Buku Teks Fakultas Studi Islam, Universitas al-Azhar, 1994-1995.

Nadiah, Mahmud Mustafa. Al-Daulah al-Abbasiyah; min al-Takhalliy'an 
Siyasat al-Fath ila al-Suqut, Cet. I. Kairo: al-Ma'had al-'Alamiy li al-Fikr al-Islamiy, 1996.

Nasution, Harun. Islam Ditinjau dari Berbagai Aspeknya, Jilid I, Cet. V. Jakarta: UI Press, 1990.

Shaban. Sejarah Islam (600-750): Penafsiran Baru, terj. Machnun Husein, Cet. I. Jakarta: PT. Raja Grafindo, 1993.

al-Suyuthi, Jalal al-Din. Tarikh al-Khulafa wa al-Umara, Cet. I. t.tt: t.p., $1408 \mathrm{H} / 1988 \mathrm{M}$.

Yatim, Badri. Sejarah Peradaban Islam: Dirasah Islamiyah II. Jakarta: PT. Raja Grafindo Persada, 2003.

al-Zahabiy, Syamsuddin Muhammad bin Ahmad bin Usman. Tarikh alIslam wa Wafayat al-Masyahir wa al-A'lam ahdu Mu'awiyah ibn Abi Sufyan. Beirut: Dar al-Kitab al-Arabi, 1413 H/ 1992 M. 